\title{
VALUE ORIENTED DEVELOPMENTAL INTERACTION CAPABILITY: A DRIVER FOR TEAMWORK PERFORMANCE
}

\author{
Endang SULISTIYANI ${ }^{1}$, Augusty Tae FERDINAND ${ }^{2}$ \\ ${ }^{1}$ Business Administration Department, Politeknik Negeri Semarang, Indonesia \\ ${ }^{2}$ Management Department, Diponegoro University, Semarang, Indonesia \\ E-mails: ${ }^{1}$ endangsulis15@polines.ac.id (corresponding author); ${ }^{2}$ augusty@live.undip.ac.id
}

Received 03 August 2018; accepted 11 November 2018

\begin{abstract}
The objective of this research is to develop a conceptual model, by proposing the concept of value oriented developmental interaction capability, to fill in the research gap between knowledge sharing and team performance among the functional teams in the organization, then testing the model in the hotel industries in Yogyakarta Special Region and Central Java Province in Indonesia. Adopting the interaction theory and the concept of work values, the concept of value oriented developmental interaction capability is introduced and inserted in the research model for mediating the influence of knowledge sharing to teamwork performance. A purposive sampling is adopted in inviting employee in a hospitality industry sector to participate in this research. Following the acceptance of the regression coefficients, the Sobel test statistics is conducted and proving the role of value oriented developmental interaction capability as a mediator between knowledge sharing and teamwork performance.
\end{abstract}

Keywords: knowledge sharing, value oriented developmental interaction capability, teamwork efficacy, teamwork performance, work value, Indonesia.

JEL Classification: D23, D83, L88, O34.

\section{Introduction}

In coping with the environmental dynamics, teamwork is considered as an effective medium for encouraging process of sharing of interpersonal potentials and creating ways to work-process improvement. Team work has become an organizational way of life through which employees could work effectively (Han and Beyerlein 2016). Adopting the study of Han et al. (2017), a work process could be seen as an affective process as well as cognitive process. When a work process is understood as a cognitive process, team member will emphasizes the importance of knowledge, applying knowledge to enhance the functioning of the team (Mesmer-Magnus et al. 2017), through knowledge and experience sharing between team members a teamwork could enhance the teamwork effectiveness (Shuffler et al. 2011). As a cognitive process in a teamwork as studied by Edmondson (2012) work process may be seen as a learning process and knowledge sharing that provide ways for understanding goals better and act properly to achieve goals. Furthermore, when a work process is understood as an affective process, team member then will involve in the work process with feeling of interested, responsible, responsiveness, exited, strong motivation, attentive, inspired, enthusiastic to all pro-growth changes such as studied in the seminal work in positive and negative affect of Watson et al. (1988)

Knowledge sharing in an organization occurs as a teamwork member's response lack of proficiency such as knowledge, skill and experience. Therefore, knowledge sharing across individuals, teams, or work units could be seen as a media for identify, capture, create, and collect new knowledge to improve work capacity, core competency, and problem-solving ability, especially in dealing with the dynamic of environmental change (Wang and Wang 2012).

Copyright $\odot 2018$ The Authors. Published by VGTU Press.

This is an Open Access article distributed under the terms of the Creative Commons Attribution License (http://creativecommons.org/licenses/by/4.0/), which permits unrestricted use, distribution, and reproduction in any medium, provided the original author and source are credited.. 
Our literature review indicated an inconclusive influence of knowledge sharing in improving the teamwork performance, such as in one side studies of (Han et al. 2017, Park and Lee 2014, Tung and Chang 2011) and Chiu and Chien (2015) demonstrated the pivotal influence of knowledge sharing to teamwork performance. In the contrary, studies by scholars such as Choi et al. (2010), Xiao et al. (2016) indicated no direct impact of knowledge sharing on team performance. Consenting to the different conclusion of those research as a gap for further elaboration of the relationship between knowledge sharing and teamwork performance, we are allured to raise a question on even if knowledge sharing has potential to enhance teamwork performance, but what process should be initiated by a knowledge sharing practice that impacting positively to a teamwork performance

Adopting the work of Karpen et al. (2015) on interaction, we synthesize a concept of value oriented developmental interaction capability as a consequence of knowledge sharing leading for enhancing the team work performance as discussed in our literature review section. Hence, the objective of this study is to propose a conceptual model on a process how knowledge sharing could be managed to improve team-work performance and be tested in a hospitality industry in Indonesia.

\section{Literature review and hypothesis development}

\subsection{Knowledge sharing in a teamwork}

Study on knowledge sharing has attracted scholars at least in this decade in exploring the nature, social role as well as its professional role, and the importance of knowledge sharing in enhancing performance (Aubke et al. 2014, Ferdinand and Wahyuningsih 2018, Ghobadi 2015, Matošková and Směšná 2017, Mueller 2014, Nesheim and Hunskaar 2015, Nissen et al. 2014, Wulandari et al. 2018). Knowledge sharing within a teamwork members impacts on feeling of meaningfulness while information giving activity positively impacts on productivity (Aubke et al. 2014). Knowledge sharing or knowledge exchange between team member through the activity of Teaching each other in the team, pass on the learned knowledge and sharing of unsuccessful experience is recognized as tools for enhancing team member innovativeness leading for better performance (Ferdinand and Wahyuningsih 2018). One of the basic dimension in knowledge sharing process is interactions between members that may influenced by of impacted to motivation, attitude, knowledge, and skill (Matošková and Směšná 2017) leading to a better performance. Knowledge sharing between team is a vital to organization-wide learning which is driven by output orientation an openness in team members (Mueller 2014). Knowledge sharing will be more intensive in an "in-group" compared to "out-group" as strong trust between members in an "in-group" is a driver for knowledge sharing behavior (Nesheim and Hunskaar 2015).

Moreover, when team member experiences a complex situation as called as critical moment of work, the knowledge sharing is a way for Sharing information on important tasks, sharing new ideas to solve confusing and uncertain tasks, sharing ways in coping with tight work schedules (Wulandari et al. 2018) and directly impact of teamwork quality leading to a better performance (Wulandari et al. 2018). Knowledge sharing may be conducted as a horizontal as well as vertical knowledge sharing (Urbancová and Fejfarová 2015). If knowledge sharing or knowledge transfer happens horisontally, indicating the sharing within one generation of employees such as among current employees, among current teamwork members. If knowledge sharing happened vertically, it is indicating sharing of knowledge between generations of employees such as sharing from current employees to subordinates, from a current team work to their downline teamwork in a same area of work. The current study is focusing on the horizontal knowledge sharing as means for empowering a teamwork.

In summary, knowledge sharing may be understood as a willingness to help others or to learn with others (Hau and Chow 2012). The sharing of tacit and explicit knowledge may occurs between individuals, teams, or organizations through formal and informal media (Noor and Salim 2011). Current development of technology has facilitated the distribution of knowledge through various media and collaborative softwares such as e-learning, teleconference, net-based phone, e-mail, and online community, individually or in a group. Knowledge sharing occurs not only in form of communication and sharing ideas, but also sharing strengths, fulfilling necessities of organizational members, broadcasting success stories and achievements, and even solving collective problems.

Knowledge sharing at work place is an activity of distributing or exchanging in explicit or tacit ways knowledge, ideas, experiences, skills, or technologies across employees or in a teamwork. Knowledge shall be transferable vertically from up to down, or from down to up, and also horizontally. During knowledge sharing process, participants may interact to each other through face-to-face relationship or non-contact connection through written documents or virtual community (Al-Zu'bi 2011). According to Blumentritt and Johnston (1999), knowledge sharing at work place requires understandings on know-how, know-what, knowwhy, and know-when. Employees' values and trust can be attained through accumulation of experiences, and whether it is attainable or not is directly determined by employees (Nonaka and Takeuchi 1995). Sharing stories, internship, or face to face relationship are few methods of knowledge 
sharing. Through this sharing, members of teamwork may share interpersonal strengths to increase their insights and experiences. Knowledge sharing is an important process in a team because when knowledge is not shared, then cognitive resources available in the team will be less utilized (Argote 2013). Knowledge sharing in a team work refers to a process of sharing ideas, experiences, information, and advices across team members. Knowledge sharing can help the team to establish a collective mental model, and this activity may positively affect job implementation and team coordination, which possibly results in higher team performance. Thus, better team performance could be enhanced through knowledge sharing, for two reasons, the first is knowledge sharing is a media forimproving a teamwork decision-making and the second is knowledge sharing facilitates the coordination between team member (Srivastava et al. 2006). As demonstrated by the previous study, knowledge sharing among organizational team members is always aimed for better team performance (Han et al. 2017, Pangil and Moi Chan 2014).

\subsection{Value oriented developmental interaction capability}

As knowledge sharing practices take place in an interaction process between teamwork members with two folds of cognitive and affective process (Han et al. 2017). First is as a cognitive process of sensing and knowing for clarifying work and its related attributes, second as an affective process that enegergizing team member for having positive feeling on work, being responsible and responsiveness, exited in sharing for better, strong motivation for searching ways for doing better, being inspiring and inspired in a teamwork for creating ways in enhancing performance. Both teamwork and knowledge sharing by nature is an interaction setting. Teamwork is an interaction between members with a shared objective, while knowledge sharing is a developmental interaction process for being knowledgeable and capable in performing better as defined by Karpen et al. (2015, p. 91) that developing interaction is "An organization's ability to assist individual actors' knowledge and competence development within the service system". As depicted in the definition, an interaction should result in a developmental initiative, making ways for contributing with new attributes that perceived by team work members as a kind of added value leading to enhancing performance. For individual workers, added value may come out as new knowledge and skill, new way of thinking, new way of doing in the workplace, new ways of solving bottleneck along the organizational work life. The ability of creating added value through a developmental interaction in this study is called value oriented developmental interaction capability. If interaction is directed to develop a certain work values, an intriguing question is what kind of values will be searched and developed? Adopting the study of Schweitzer et al. (2015), using an interaction process, a worker may look for and creating or enhancing several values amongst others: 1. Extrinsic work values such as information, job security, and recognition; 2 . Intrinsic work values such as achievement, advancement, challenge, continuously learn; 3. Social/altruistic work values such as Co-workers, Fun, help people, social interaction; 4 . Prestige work values such as authority, influence, prestigious and influencing. The effort and capability in creating or enhancing those values for individuals through the interaction process may be understood as a value oriented developmental interaction capability.

Knowledge sharing as a process of exchanging ideas, skills, experiences between teamwork member hold a potential for enhancing capability between the teamwork members in the form of exchanging, utilizing, and disseminating information, experience, practice, insight and general understanding (Wang et al. 2016), and enhancing work value (Schweitzer et al. 2015) therefore, the following hypothesis is proposed.

H1: knowledge sharing positively influences value oriented developmental interaction capability.

\subsection{Team efficacy and team performance}

Success of a teamwork is determined by the the capability as well as quality of a teamwork. Study on employee efficacy has become a mainstream concept in explaining performance. Referring to the work of Bandura (1997) teamwork-efficacy could be understood as a collective belief in capability or judgments of what they can do with their knowledge and skill to accomplish a specific job effectively. Adopting the study of Ambrozová et al. (2016) teamwork efficacy may be understood as meta skill that is created in the background of individual and include implicit knowledge and hard skills as well as soft skills that collectively and effectively disseminated in a teamwork. As a team is a collective portfolio of persons with a certain knowledge and skill or capability, team work efficacy would be constructed when team members are regularly making effort in bridging individual differences in teamwork, hand in hand particularly in a challenging situations, and continually capitalize on the strengths of each member (Lent et al. 2006).

Learning from the study of Kozlowski and Klein (2000) and (Budworth 2011), team member efficacy may be developed in several ways such as 1 . Social interaction and sharing of interpretation on a certain issues, exchanging of experience in solving a problem, 2. Integrating self-efficacy through reducing the team member's variability of differences and perceptions, facilitating common interpretations 
of the course of action in accomplishing a job. 3. As we may consider the individual difference factors of team members might have an impact on the relationship within the team, training and knowledge sharing routines could decrease the individual differences and increase the collective efficacy in a teamwork. These ways may occur as the team members having a value oriented interaction capability through the knowledge sharing process within the team work, therefore the following hypothesis is proposed.

H2: Value oriented developmental interaction capability positively influences teamwork efficacy.

As mentioned that teamwork efficacy demonstrated a collective belief and effective judgment of what they can do with watever skill they have (Bandura 1997), it is reasonable that teamwork with high efficacy could produce more achievement in performance (Budworth 2011). Therefore, the following hypothesis is proposed

H3: Teamwork efficacy positively influences work team performance.

\subsection{Value oriented developmental interaction capability and teamwork performance}

Teamwork is individuals who are attached in work units of an organization, and therefore, the effective function of the organization must depend greatly on team capability (Mathieu et al. 2008). A team will implement interaction process, share knowledge, and transform individual knowledge into team knowledge. The shared knowledge will be gathered, combined, considered, and integrated to become more valuable new knowledge. Interaction of work team members in developing team knowledge will be the stepping stone for the founding of knowledge management team, which in turn, helps to initiate the birth of creative team (Sung and Choi 2012). This creative team shall have a potential to be successful always in achieving work targets, in applying creative ideas, and in making products with good quality. Schweitzer et al. (2015) describes what employees are looking for in his/ her work and concludes the intrinsic work values such as achievement, advancement, challenge, continuously learn as something an employee builds in the career for boosting his/her capability. Therefore, it is reasonable that the value he/she develop and maintain could lead to a better performance. In summary, the following two hypotheses are proposed.

H4: Value oriented developmental interaction capability positively influences work teamwork performance.

H5: Value oriented developmental interaction capability mediates the influence on knowledge sharing to teamwork performance.

\section{Research method}

\subsection{Sample and data collection}

To test our hypothesized model, we choose a sector of hospitality industry that is hotel companies that is registered and member of Indonesian Hotel and Restaurant Association, for several reason. First, hotel industry in a labor-intensive business, highly based on value provided since guest check in time until the time after checking out. 2. As a labor-intensive business, the role of employee with his/her humanistic touch is important in serving customers. 3. Meta skill of a worker as individual or as a team member is important representing his/her self-efficacy as well as teamwork efficacy. A number of 42 three, four- and five-star hotels are participated in this research. We directed out study to the functional team in hotel industries in Central Java and Yogyakarta Special District Indonesia. A purposive sampling technique is used with several criteria as follows: 1. they should be in a teamwork in the position of head of the department, supervisor and strategic staff. 2 . They should have a minimum 5-year experience in the job.

A total number of 570 employees in 190 teamwork of 42 hotels are contacted for participating in answering the questionnaire. After data collecting period, we received 519 reliable responses working in 173 teams.

\subsection{Measurement of variables}

Team work performance is measured by scales used in Lurey and Raisinghani (2001) and (Salas et al. 2017) in the following items: 1 . Our teamwork successfully achieve target on time; 2. Our team is successfully implementing the new ideas and practices; 3 . Our team successfully to achieve the Job target. Knowledge sharing scale is adapted from Reychav and Weisberg (2010) and Wang et al. (2014) with three items as follows: 1 . "I frequently share new information as I consider as an important information to the team members", 2.'I will be willing to share/I share work reports and official documents that I prepare by myself with members", 3. "I frequently share ideas about how to achieve target and evaluation of work". Value oriented developmental interaction capability is a new scale adapted from the study of Derksen et al. (2011) and Karpen et al. (2015) as measured using the following scales 1 . We are interacting for improving the work process; 2 . We are interacting actively in combining our knowledge and skills; 3 . We are interacting for getting ways in increasing our individual capacity. Measurement of teamwork efficacy is developed by adopting the scale used in Lent et al. (2006) and presented as the following: 1. We have more confidence in implementing our job; 2 . We are effectively bridging the individual differences between team members; 3 . We are effectively utilizing our interpersonal power in completing out work. 
Each scales are presented in question items and measured using an anchored scale as suggested by Nunnally and Bermstein (1994) for getting an interval scale, using a numerical scale with measurement of 1 until 10. The very left-hand side of the scale is one denoting very disagree, and the very right-hand side is ten referring to agree very much.

\section{Data analysis and findings}

\subsection{Data analysis}

Data were analyzed using Structural Equation Modeling (SEM) statistic software of AMOS 24.0 for identifying the measurement model and analysis the causal relationship and regression magnitude as well as for the goodness of fit of the model (Arbuckle 2016). The mediation effect of the variable is tested using Sobel test analysis (Hayes 2013). Validity and reliability tests such as construct reliability, variance extracted, and intra-class reliability are provided in Table 1.

Based on loading factors of the indicator of the constructs, every single variable has a cut-off value of $\geq 0.50$, indicating the magnitude of loading factor is well mirroring the constructed variable. Construct reliability has a suggested cut off value to be $\geq 0.7$, while the cut of the value of average variance extracted is suggested to be $\geq>0.5$ (Hair et al. 2010). The intraclass-correlation coefficient (ICC), is a descriptive statistic for measuring units that are organized into groups is used. ICC score is calculated based on the estimated value of individual reliability within the team as well as the number of individual-level response voices that can ensure that the individual respondent's level of data corresponds to the aggregate described in team level (Bliese 2000, James 1984). The cut-off value of ICC is $\geq 0.70$ (George 1990). ICC value for knowledge sharing is 0,932 ; value oriented developmental interaction capability is to 0.937 ; team efficacy is 0.910 , and team performance is 0.937 , all are above cut-off value of 0.70 a level of aggregation has been confirmed, in other words, the mean of individual variable values is equal to the mean values at the teamwork level. Measurement of the construct variable, convergent validity, construct reliability, and the interclass correlation coefficients are presented in the Table 1 .

\subsection{Hypothesis testing}

To test our model and hypothesis, firstly the structural model analysis was conducted, and the result is presented in the Figure 1. The computation of the data resulted the Goodness of fit test using statistical measure of chi-square = 60.505 with significance level of 0.147 or $>0.05$ indicating the acceptance of the model. Several indicator of non- statistical measure such as GFI $=0,945$; AGFI $=0.914$; $\mathrm{TLI}=$ $0.993 ; \mathrm{IFI}=0.992 ; \mathrm{CFI}=0.995$ are above the cut-off value of $\geq 0.90$ with the value of RMSEA $=0.035$ within the cut-off

Table 1. Measurement validity and reliability (source: author's data processing)

\begin{tabular}{|c|c|c|c|c|c|}
\hline Variable \& Indicator & Source & $\begin{array}{l}\text { Std. esti- } \\
\text { mate }\end{array}$ & $\begin{array}{c}\text { Convergent } \\
\text { validity- } \\
\text { AVE }\end{array}$ & $\begin{array}{l}\text { Construct } \\
\text { reliability }\end{array}$ & ICC \\
\hline \multicolumn{6}{|l|}{ CFA Exogenous Variable: } \\
\hline - Knowledge Sharing & \multirow{4}{*}{$\begin{array}{l}\text { Reychav and } \\
\text { Weisberg } \\
\text { (2010) and } \\
\text { Wang et al. } \\
(2014) \text {. }\end{array}$} & & 0.827 & 0.978 & 0.932 \\
\hline - Sharing new important information & & 0.911 & & & \\
\hline - Sharing reports and official documents & & 0.937 & & & \\
\hline - Sharing ideas on how to achieve targets & & 0.880 & & & \\
\hline \multicolumn{6}{|l|}{ CFA Endogenous Variable: } \\
\hline - Value oriented Developmental Interaction Capability & \multirow{4}{*}{$\begin{array}{l}\text { Derksen et al. } \\
(2011) \text { and } \\
\text { Karpen et al. } \\
(2015)\end{array}$} & & 0.835 & 0.980 & 0.937 \\
\hline - Interaction for updating the work process & & 0.949 & & & \\
\hline - Interaction for combining knowledge and skills & & 0.874 & & & \\
\hline - Interaction for increasing individual capacity & & 0.917 & & & \\
\hline Teamwork Efficacy & \multirow{4}{*}{$\begin{array}{l}\text { Lent et al. } \\
(2006)\end{array}$} & & 0.783 & 0.961 & 0.910 \\
\hline - Confidence in job implementation & & 0.776 & & & \\
\hline - Effectiveness in bridging individual differences & & 0.980 & & & \\
\hline - Effectiveness in Interpersonal power boosting for job & & 0.887 & & & \\
\hline Teamwork Performance & \multirow{4}{*}{$\begin{array}{l}\text { Lurey and } \\
\text { Raisinghani } \\
(2001) \text { and } \\
\text { Salas et al. } \\
(2017)\end{array}$} & & 0.805 & 0.979 & 0.937 \\
\hline - On time target achievement & & 0.902 & & & \\
\hline - New ideas implementation success & & 0.939 & & & \\
\hline - Job target accomplishment & & 0.897 & & & \\
\hline
\end{tabular}


value of between $0.03-0.08$ (Arbuckle 2016), therefore the goodness of fit of the model is achieved.

Regression coefficient of the hypothesized path $\mathrm{H} 1=$ 0.964; $\mathrm{H} 2=0.233 ; \mathrm{H} 3=0.172$ and $\mathrm{H} 4=0.471$ with the critical ratio or t-value $>2.0$, precisely 1.96 (Arbuckle 2016) indicating the acceptance of all hypotheses in the model (Table 2).

\subsection{Mediating effect}

To tests our mediating relationship between knowledge sharing, value oriented developmental interaction capability, we run the mediating test using the Sobel test (Ferdinand 2014) resulting a statistical test $Z$ value $=6.1717$ larger the cut of value of 1.96 indicating the existence of mediating effect of the tested variable.

\section{Research contribution and direction for future research}

\subsection{Research contribution}

The current study is questioning about the process how knowledge sharing could be managed to improve teamwork performance in a perspective of interaction theory for creating values of work and efficacy of teamwork in an organization. Based on the support of our hypotheses, several findings will be discussed as follows.

Firstly, our study demonstrated the importance of knowledge sharing in organization, especially in enhancing a value oriented developmental interaction capability of employee in a teamwork setting. The values of work may be described as firstly, work process updated through well-organized information through interaction within the

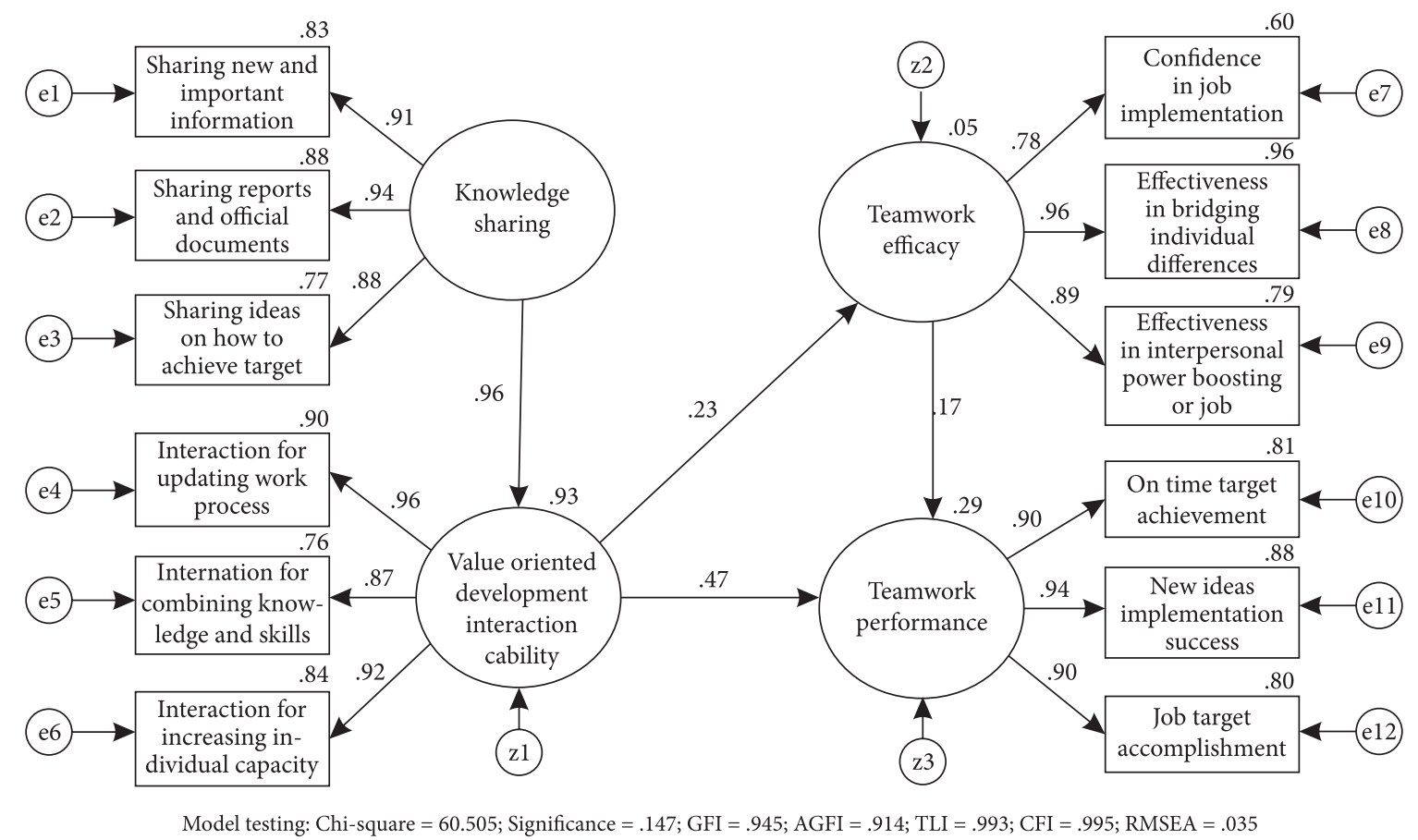

Figure 1. Full structural equation model

Table 2. The result of regression test

\begin{tabular}{|l|c|c|c|c|}
\hline \multicolumn{1}{|c|}{ Hypothesis } & $\begin{array}{c}\text { Standardized } \\
\text { estimate }\end{array}$ & Critical ratio & p-value & Result \\
\hline $\begin{array}{l}\text { H1: Knowledge sharing } \rightarrow \text { Value oriented developmental } \\
\text { interaction capability }\end{array}$ & 0.964 & 16.839 & $0.000^{*}$ & Supported \\
\hline $\begin{array}{l}\text { H2: Value oriented developmental interaction capability } \rightarrow \\
\text { Teamwork efficacy }\end{array}$ & 0.233 & 2.953 & $0.003^{*}$ & Supported \\
\hline H3: Teamwork efficacy $\rightarrow$ Teamwork performance & 0.172 & 2.403 & $0.016^{* *}$ & Supported \\
\hline $\begin{array}{l}\text { H4: Value oriented developmental interaction } \\
\text { capability } \rightarrow \text { Teamwork performance }\end{array}$ & 0.471 & 6.356 & $0.000^{*}$ & Supported \\
\hline $\begin{array}{l}\text { H5: Value oriented developmental interaction capability } \\
\text { mediates the influence of knowledge sharing to teamwork } \\
\text { performance }\end{array}$ & & Z-value $=6.1717$ & Supported \\
\hline
\end{tabular}

${ }^{\star}=$ significance level of $\leq 1 \%,{ }^{* *}=$ significance level of $\leq 5 \%$ 
teamwork, recognition of self-competence as an extrinsic work value; 2 . Integrating knowledge and skills for selfadvancement, feeling of continuous learning as a personal need and mastering ways for coping with organizational challenge as Intrinsic work values; 3. Get empowered personal capability a an influencing person for helping the others in the teamwork as a prestige work values cultivated in a team member. Those values are cultivated in an interaction process. This finding is an operationalization of Karpen et al. (2015) and Schweitzer et al. (2015) studies on interaction and value of work leading to the concept of value oriented developmental interaction capability. The acceptance of the hypothesis on the influence of knowledge sharing to value oriented developmental interaction capability demonstrated the power of organizational learning concept that when people are interact and exchanging explicit and or tacit knowledge in an organization level such as in a teamwork, this type of knowledge sharing will boosting capability in doing work (Wulandari et al. 2018).

Secondly, the current study is improving our knowledge on a strategic antecedence for enhancing a teamwork efficacy. As mentioned by Bandura (1997) that teamwork-efficacy is a collective belief in capability or judgments of what they can do or a conceptualized by Ambrozová et al. (2016) that a team efficacy is a meta skill that is created through the work life of an employee in terms implicit knowledge and hard skills as well as soft skills, the findings of this study is that when employee was empowerd with a value oriented developmental interaction capability, they will be more efficacy in the teamwork for dloling whatever job or work in their responsibility area. The current study proved that having a value oriented developmental interaction capability will boost teamwork confidence in handing and completing a job effectively, increasing the effectiveness in bridging the individual difference to be a collective efficacy in a teamwork, and a value oriented developmental interaction capability may be a tool for interpersonal power boosting in a teamwork. Furthermore, Donohoo (2017) explained the collective efficacy is directly affecting team members' perseverance in finishing the tasks and in achieving team goals due to being energetic in pursuing positive outcomes. If they believe that they can achieve the best work, they will work hard to make it real.

Thirdly, considering the magnitude of the regression coefficient, even though teamwork efficacy is key determinant for enhancing performance, this study pinpoints the important of value oriented developmental interaction capability in enhancing teamwork performance for several reasons. Involving in an developmental interaction process, employee may develop his/her meta skills (Ambrozová et al. 2016) for individuals such as Meta skills embedded personally including explicit and implicit knowledge and soft and hard skills for boosting a performance. Therefore maintaining regularly this value oriented meta skills process through interaction would enhance personal capability in handling work issues particularly the critical moment of work in the teamwork (Wulandari et al. 2018) as an intellectual capital for enhancing teamwork performance.

Fourthly, the acceptance of our mediating hypothesis substantiates the role value oriented developmental interaction capability as a leverage for teamwork performance. The rationale behind this notion is a knowledge sharing process should be directed to gain values in a teamwork for building personal as well as teamwork capability such as self-confidence, self-advancement, empowered capability as tool for enhancing performance. When the team members are capable of exploiting their knowledge, they will produce new technique and skill that strengthens their motivation and capacity to deal with challenging tasks. Han et al. (2017) discovered organizational members who work as a team will combine their knowledge, skills, and abilities to solve a complex problem. As shown in the study of Karpen et al. (2012) the capability to interact will boost a competency for teamwork members as a prerequisite for improving performance.

\subsection{Future research}

The introduction of the Value oriented developmental interaction capability in this study is a new initiative in explaining the process how knowledge sharing could improve teamwork performance. As commonly happened in a scientific research, several limitations of the study should be addressed and followed by possible future research. First limitation is sample scope is only in one hospitality industry, i.e., hotel companies, bringing a consequence of limitation in the generalizability of this findings. Therefore, a further research should be directed to test the concept in a multi firm and multi industry setting. Second limitation, the ontology of the value oriented developmental interaction capability is defined directly in indicators mirroring the concept. Therefore future study to construct the dimension of this concept is open for further research.

\section{Acknowledgment}

Special acknowledgment is for our respondents: managers, supervisors and strategic staff in the hotel industries at Central Java and Yogyakarta Special District Indonesia who had participated in the research.

\section{References}

Al-Zu'bi HA (2011) Organizational citizenship behavior and impacts on knowledge sharing: an empirical study. International Business Research 4 (3): 221-227. https://doi.org/10.5539/ ibr.v4n3p221 
Ambrozová E, Koleňák J, Pokorný V (2016) Connatural management approach to preparation and development of individuals in the business environment. Business: Theory and practice - Verslas: Teorija ir Praktika 17 (2): 81-88. https:// doi.org/10.3846/btp.2016.512

Arbuckle JL (2016) IBM $^{\circledast}$ SPSS $^{\circledast}$ Amos $^{\text {Tx }}$ User’s Guide.

Argote L (2013) Organizational learning creating, retaining and transferring knowledge (2nd ed). New York: Springer.

Aubke F, Wöber K, Scott N, Baggio R (2014) Knowledge sharing in revenue management teams: antecedents and consequences of group cohesion. International Journal of Hospitality Management 41: 149-157. https://doi.org/10.1016/j.ijhm.2014.05.010

Bandura A (1997) Self-efficacy: the exercise of control. New York: W. H. Freeman

Bliese PD (2000) Within-group agreement, non-independence, and reliability implication for data aggregation and analysis. San Fransisco: Jossey-Bass.

Blumentritt R, Johnston R (1999) Towards a strategy for knowledge management. Technology Analysis \& Strategic Management 11 (3): 287-300. https://doi.org/10.1080/095373299107366

Budworth M-H (2011) Individual learning and group performance: the role of collective efficacy. Journal of Workplace Learning 23 (6): 391-401. https://doi.org/10.1108/13665621111154403

Chiu Y-W, Chien Y-C (2015) The effect of knowledge sharing on organizational performance organizational learning as mediator. International Journal of Information Technology and Business Management 36 (1). https://doi.org/10.2495/ AMEIT14

Choi SY, Lee H, Yoo Y (2010) The impact of information technology and transactive memory systems on knowledge sharing, application, and team performance a field study. MIS Quarterly 34 (4): 855-870. https://doi.org/10.2307/25750708

Derksen K, de Caluwé L, Simons RJ (2011) Developmental space for groups working on innovation. Human Resource Development International 14 (3): 253-271. https://doi.org/10.10 $80 / 13678868.2011 .585060$

Donohoo J (2017) Collective teacher efficacy research: implications for professional learning. Journal of Professional Capital and Community 2 (2): 101-116. https://doi.org/10.1108/ JPCC-10-2016-0027

Edmondson AC (2012) Teaming: how organizations learn, innovate, and compete in the knowledge economy. San Francisco, CA: John Wiley\&Sons.

Ferdinand A (2014) Metode penelitian anajemen: Pedoman penelitian untuk penulisan skripsi, tesis dan disertasi ilmu manajemen - Management Research Method: a research guidance for writing thesis and dissertation in management science (Vol. 5). Semarang: Undip Press - Badan Penerbitan Undip.

Ferdinand AT, Wahyuningsih W (2018) Salespeople's innovativeness: a driver of sales performance. Management \& Marketing. Challenges for the Knowledge Society 13 (2): 966.

George JM (1990) Personality, affect, and behavior in groups. Journal of Applied Psychology 75 (2): 107-116. https://doi. org/10.1037/0021-9010.75.2.107

Ghobadi S (2015) What drives knowledge sharing in software development teams: a literature review and classification framework. Information \& Management 52 (1): 82-97. https:// doi.org/10.1016/j.im.2014.10.008
Hair JF, Black WC, Babin BJ, Anderson RE (2010) Multivariate data analysis ( $\left.7^{\text {th }} \mathrm{Ed}\right)$. Pearson Prentice Hall.

Han SJ, Beyerlein M (2016) Framing the effects of multinational cultural diversity on virtual team processes. Small Group Research 47 (4): 351-383. https://doi.org/10.1177/ 1046496416653480

Han SJ, Lee Y, Beyerlein M, Kolb J (2017) Shared leadership in teams the role of coordination, goal commitment, and knowledge sharing on perceived team performance. Team Performance management: an International Journal.

Hau I, Chow S (2012) The role of social network and collaborative culture in knowledge sharing and performance relations. SAM Advanced Management Journal 77 (2): 24-37.

Hayes AF (2013) Methodology in the social sciences, Introduction to mediation, moderation, and conditional process analysis: a regression-based approach. New York, NY: US: Guilford Press.

James LR (1984) Estimating within-group interrater reliability with and without response bias. Journal of Applied Psychology 69 (1): 85-98. https://doi.org/10.1037/0021-9010.69.1.85

Karpen IO, Bove LL, Lukas BA (2012) Linking service-dominant logic and strategic business practice. Journal of Service Research 15 (1): 21-38. https://doi.org/10.1177/1094670511425697

Karpen IO, Bove LL, Lukas BA, Zyphur MJ (2015) Service-dominant orientation: measurement and impact on performance outcomes. Journal of Retailing 91 (1): 89-108. https://doi. org/10.1016/j.jretai.2014.10.002

Kozlowski SWJ, Klein KJ (2000) A multilevel approach to theory and research in organizations contextual, temporal, and emergent processes. Francisco: Jossey-Bass.

Lent RW, Schmidt J, Schmidt L (2006) Collective efficacy beliefs in student work teams: relation to self-efficacy, cohesion, and performance. Journal of Vocational Behavior 68 (1): 73-84. https://doi.org/10.1016/j.jvb.2005.04.001

Lurey JS, Raisinghani MS (2001) An empirical study of best practices in virtual teams. Information \& Management 38: 523-544. https://doi.org/10.1016/S0378-7206(01)00074-X

Mathieu J, Maynard MT, Rapp T, Gilson L (2008) Team effectiveness 1997-2007 a review of recent advancements and a glimpse into the future. Journal of Management 34 (3): 410476. https://doi.org/10.1177/0149206308316061

Matošková J, Směšná P (2017) Human resource management practices stimulating knowledge sharing. Management \& Marketing 12 (4).

Mesmer-Magnus J, Niler AA, Plummer G, Larson LE, DeChurch LA (2017) The cognitive underpinnings of effective teamwork: a continuation. Career Development International 22 (5): 507-519. https://doi.org/10.1108/CDI-08-2017-0140

Mueller J (2014) A specific knowledge culture: cultural antecedents for knowledge sharing between project teams. European Management Journal 32 (2): 190-202. https://doi. org/10.1016/j.emj.2013.05.006

Nesheim T, Hunskaar HM (2015) When employees and external consultants work together on projects: challenges of knowledge sharing. International Journal of Project Management 33 (7): 1417-1424. https://doi.org/10.1016/j.ijproman.2015.06.010

Nissen HA, Evald MR, Clarke AH (2014) Knowledge sharing in heterogeneous teams through collaboration and cooperation: 
exemplified through public-private-innovation partnerships. Industrial Marketing Management 43 (3): 473-482. https:// doi.org/10.1016/j.indmarman.2013.12.015

Nonaka I, Takeuchi H (1995) The knowledge creating company. New York: Oxford University Press.

Noor IM, Salim J (2011) Factors influencing employee knowledge sharing capabilities in electronic government agencies in Malaysia. IJCSI International Journal of Computer Science Issues 8 (4): 106-114.

Nunnally JC, Bermstein IH (1994) Psychometric theory (3rd ed). New York: McGraw-Hill.

Pangil F, Moi Chan J (2014) The mediating effect of knowledge sharing on the relationship between trust and virtual team effectiveness. Journal of Knowledge Management 18 (1): 92106. https://doi.org/10.1108/JKM-09-2013-0341

Park J-G, Lee J (2014) Knowledge sharing in information systems development projects: explicating the role of dependence and trust. International Journal of Project Management 32: 153165. https://doi.org/10.1016/j.ijproman.2013.02.004

Reychav I, Weisberg J (2010) Bridging intention and behavior of knowledge sharing. Journal of Knowledge Management 14 (2): 285-300. https://doi.org/10.1108/13673271011032418

Salas E, Reyes DL, Woods AL (2017) The assessment of team performance: observations and needs. Switzerland: Springer International Publishing.

Schweitzer L, Ng ESW, Kuron LKJ, Lyons ST (2015) Millennials' work values: differences across the school to work transition. Personnel Review 44 (6): 991-1009. https://doi.org/10.1108/ PR-01-2014-0024

Shuffler ML, DiazGranados D, Salas E (2011) There's a science for that: team development interventions in organizations. Current Directions in Psychological Science 20 (6): 365-372. https://doi.org/10.1177/0963721411422054

Srivastava A, Bartol KM, Locke EA (2006) Empowering leadership in management teams: effects on knowledge sharing, efficacy, and performance. Academy of Management Journal 49 (6): 1239-1251. https://doi.org/10.5465/amj.2006.23478718
Sung SY, Choi JN (2012) Effects of team knowledge management on the creativity and financial performance of organizational teams. Organizational Behavior And Human Decision Processes 118: 4-13. https://doi.org/10.1016/j.obhdp.2012.01.001

Tung H-L, Chang Y-H (2011) Effects of empowering leadership on performance in management team Mediating effects of knowledge sharing and team cohesion. Journal of Chinese Human Resource Management 2 (1): 43-60. https://doi. org/10.1108/20408001111148720

Urbancová H, Fejfarová M (2015) Vertical knowledge transfer in Czech organizations. Business: Theory and practice - Verslas: Teorija ir praktika 16 (3): 231-242. https://doi.org/10.3846/ btp. 2015.477

Wang Z, Sharma PN, Cao J (2016) From knowledge sharing to firm performance: a predictive model comparison. Journal of Business Research 69 (10): 4650-4658. https://doi. org/10.1016/j.jbusres.2016.03.055

Wang Z, Wang N (2012) Knowledge sharing, innovation and firm performance. Expert Systems with Applications 39: 88998908. https://doi.org/10.1016/j.eswa.2012.02.017

Wang Z, Wang N, Liang H (2014) Knowledge sharing, intellectual capital and firm performance. Management Decision 52 (2): 230-258. https://doi.org/10.1108/MD-02-2013-0064

Watson D, Clark LA, Tellegen A (1988) Development and validation of brief measures of positive and negative affect: the PANAS scales. Journal of Personality and Social Psychology 54 (6). https://doi.org/10.1037/0022-3514.54.6.1063

Wulandari F, Ferdinand AT, Dwiatmadja C (2018) Knowledge Sharing in a critical moment of work. International Journal of Knowledge Management 14 (2): 88-98. https://doi. org/10.4018/IJKM.2018040106

Xiao Y, Zhang H, Basadur TM (2016) Does information sharing always improve team decision making? An examination of the hidden profile condition in new product development. Journal of Business Research 69 (2): 587-595. https://doi. org/10.1016/j.jbusres.2015.05.014 